\title{
Short-term, parallel storage in the prediction of storage losses caused by Botrytis cinerea Pers ex Fr. on cabbage
}

\author{
RISTO TAHVONEN
}

Department of Plant Pathology, University of Helsinki, SF-00710 Helsinki 71, Finland

New address: Agricultural Research Centre, Institute of Plant Pathology, SF31600 Jokioinen, Finland

Abstract. The level of Botrytis cinerea Pers ex Fr. on cabbages stored for 6.5 months in a cold store $\left(+1{ }^{\circ} \mathrm{C}\right)$ and the subsequent number of merchantable cabbages were extremely reliably predicted by the $B$, cinerea contents of cabbages stored for 7 weeks at $5-10^{\circ} \mathrm{C}$, or 3.5 months at $+1{ }^{\circ} \mathrm{C}$. The cabbages were probably infected by $B$. cinerea in the field 3 weeks or more before harvesting. The fungus could still be controlled satisfactorily by spraying with fungicide 4 weeks before harvesting.

\section{Introduction}

Storage pathogens, especially Botrytis cinerea Pers ex Fr., are a considerable problem in the storage of cabbages (STRUC \& CRUTZ 1972, BROWN et al. 1975, BOCHOW et al. 1976, LOCHART 1976, KEAR et al. 1977, SEIDEL and BARESEL 1978). However, only $B$. cinerea causes significant losses to cabbages in stores where the temperature is kept close to $0^{\circ} \mathrm{C}$, although in this case the losses do not occur until after 5-7 months storage. During the initial stages of storage the fungus is only present on the outer leaves, which are normally always removed when preparing them for sale. In Finnish conditions, $B$. cinerea already infects the cabbages in the field during the growing season. The pathogen does not spread to any significant extent during storage (TAHVONEN 1981).

If the extent to which the cabbage crop has been infected by $B$. cinerea could be determined after harvesting, before the cabbages have been stored for 5 months, thén it would be possible to predict the storagability of the crop and thus ensure that it is marketed before the losses start to become significant. The aim of this study was to develop a method for determining the content of the most common storage pathogen on cabbage, $B$. cinerea, for use in predicting the storagability of the cabbages before any significant storage losses have occurred. 


\section{Materials and methods}

In 1981 and 1982, cabbages ('Faalen sinikärki') were sprayed at different times before harvesting with benomyl (Benlate), viclozoline (Ronilan) and dicyclidine (Sumisclex) fungicides in order to obtain varying Botrytis cinerea Pers ex Fr. contents on the cabbage lots when they were in storage. The spraying times and effective compound dosages are presented in Table 1.240 cabbages weighing between $1-3 \mathrm{~kg}$ each were removed from each of the treatment lots and placed in 16 perforated plastic sacks. 4 of the sacks were stored for 6.5 months at $+1{ }^{\circ} \mathrm{C}, 2$ sacks for $1.5,2.5$ and 3.5 months at $+1{ }^{\circ} \mathrm{C}$ and 2 sacks for 3,5 och 7 weeks at $+5-+10^{\circ} \mathrm{C}$. The cabbages stored for the longest period of time (6.5 months) were prepared for marketing and their $B$. cinerea contents determined (TAHVONEN 1981). Only the $B$. cinerea- $\%$ was determined on the other cabbage lots.

The effect of the fungicide treatments on the $B$. cinerea content and storagability of the cabbages was tested using analysis of variance. The correlation coefficients and the regressions $\left(y=b x+a\right.$ or $\left.y=\alpha e^{\beta x}\right)$ between the merchantability and the $B$. cinerea contents of the cabbages stored in the normal way and the $B$. cinerea contents of the cabbages kept for a short period in parallel storage were calculated.

\section{Results and discussion}

The cabbage lots kept in storage for 6.5 months differed to a highly significant degree as regords the merchantability and Botrytis sinerea Pers ex Fr. contents (Table 1). The correlation coefficient for the dependence between the $B$. cinerea- $\%$ and the merchantability was highly significant $\left(\mathrm{r}=0.91^{\mathrm{xxx}}\right)$, and thus the condition presupposed by the prediction model was fulfilled between these parameters.

Preliminary storage of cabbages at $+1{ }^{\circ} \mathrm{C}$ for 3.5 months or at

Table 1. Effect of spraying with fungicide before harvesting on the $B$. cinerea content and merchantability of cabbages stored at $+1^{\circ} \mathrm{C}$ for 6.5 months.

\begin{tabular}{|c|c|c|c|c|c|c|}
\hline \multirow[t]{2}{*}{ Fungicide } & \multirow{2}{*}{\multicolumn{2}{|c|}{$\begin{array}{l}\text { Dosage and time } \\
\text { interval before } \\
\text { harvesting }\end{array}$}} & \multicolumn{2}{|c|}{ B. cinerea-\% } & \multicolumn{2}{|c|}{ Merchantable- $\%$} \\
\hline & & & $1980 / 81$ & $1981 / 82$ & $1980 / 81$ & $1981 / 82$ \\
\hline Untreated & & & 90 & 34 & 34 & 74 \\
\hline Benomyl & $0.6 \mathrm{~kg} / \mathrm{ha}$ & 1 week & 8 & 2 & 80 & 81 \\
\hline$"$ & $0.6 "$ & 2 weeks & 10 & 5 & 80 & 77 \\
\hline$"$ & $0.6 \quad "$ & $3 "$ & 17 & 10 & 72 & 81 \\
\hline$"$ & $0.6 "$ & $4 "$ & 18 & 20 & 70 & 76 \\
\hline Vinclozoline & $0.75 "$ & $2 "$ & 23 & 5 & 77 & 70 \\
\hline$"$ & $0.75 "$ & $3 "$ & 12 & 5 & 77 & 75 \\
\hline Dicyclidine & $0.75 "$ & 1 week & 7 & 3 & 77 & 79 \\
\hline$n$ & $0.75 "$ & 2 weeks & 7 & 13 & 75 & 71 \\
\hline \multirow[t]{3}{*}{$n$} & $0.75 "$ & $3 "$ & 23 & 3 & 76 & 76 \\
\hline & \multicolumn{2}{|l|}{ F-values: } & $15.8^{\text {\#*\# }}$ & $6.5^{\text {Hस* }}$ & $28.8^{* * 4}$ & $4.9^{* * 4}$ \\
\hline & \multicolumn{2}{|l|}{ LSD $_{10.05 \%}$} & $17.9 \%$ & $11.6 \%$ & $7.4 \%$ & $4.9 \%$ \\
\hline
\end{tabular}


$+5-+10^{\circ} \mathrm{C}$ for 7 weeks gave an extremely reliable prediction of the $B$. cinerea contents of cabbages stored for 6.5 months at $+1^{\circ} \mathrm{C}$ (Fig. 1). Shorter parallel storage times at $+1^{\circ} \mathrm{C}$ predicted $0-1 / 3$ of the final pathogen content, but when a higher parallel storage temperature was used, storage times of 3 or 5 weeks already gave a reliable result for the final $B$. cinerea contents. However, in this case a microscope is needed for identifying the fungus. These results support the earlier study (TAHVONEN 1981) that the $B$. cinerea content remains fairly constant throughout the whole storage period, i.e. there is no appereciable spread of the fungus from infected to healthy cabbages during the storage period.

As the correlation between the merchantability and $B$. cinerea content of cabbages stored for a long time was extremely clear, the merchantability of cabbages to be stored for a long time could be predicted very reliably on the basis of the $B$. cinerea content of cabbages from the same lot kept in parallel storage (Fig. 2). In addition to storage pathogens, evaporation and respiration result in weight losses. However, these remain rather constant, of the order of $0.05-0.1 \%$ /day (SUHONEN 1969). The losses arising from evaporation, respiration and preparing the cabbages for sale in this study were, in the case

Fig. 1. Regression between the $B$. cinerea contents of parallelly stored cabbages and cabbages stored at $+1{ }^{\circ} \mathrm{C}$ for 6.5 months.

$\mathrm{A}=$ parallel storage at $+1^{\circ} \mathrm{C}$ for 3.5 months, $\mathrm{y}=0.809 \mathrm{x}+6.4, \mathrm{r}=0.95^{\text {क*⿻ }}$

B.C INEREA $-\%$

OF STORED CABBAGES

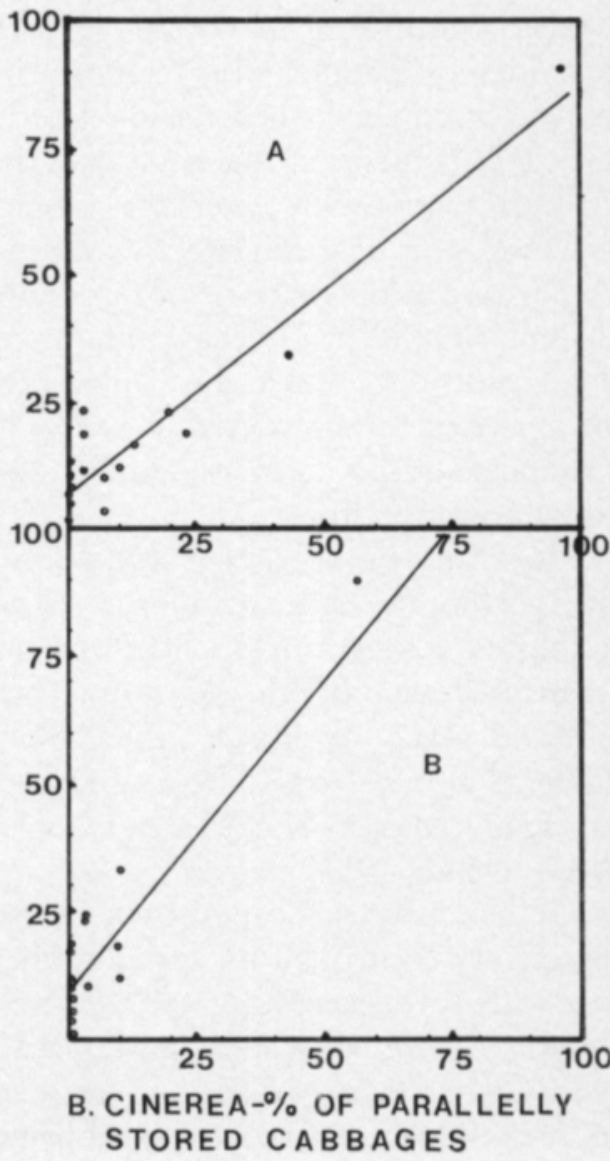

weeks, $y=1.23 x+9.3, r=0.94^{\text {*⿻⽊해 }}$ 


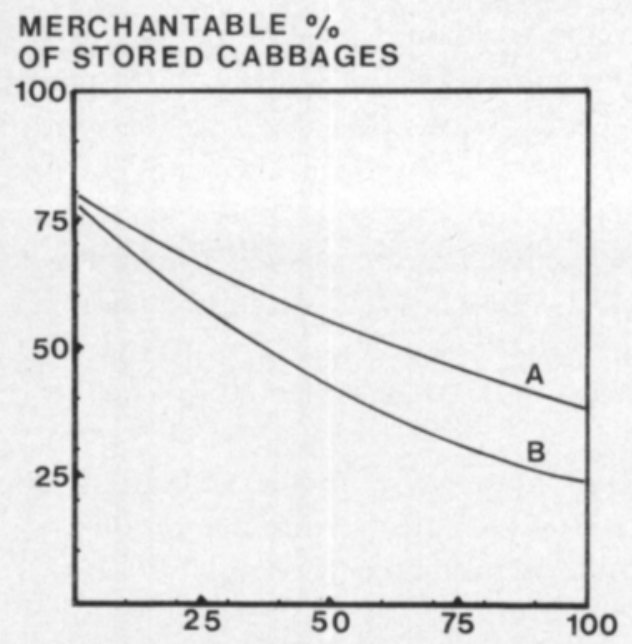

B. CINERE A - $\%$ OF PARALLELLY STORED C A B B A G S
Fig. 2. Regression between the $B$. cinerea contents of parallelly stored cabbages and the merchantability of cabbages stored at $+1{ }^{\circ} \mathrm{C}$ for 6.5 months.

$\mathrm{A}=$ parallel storage at $+1{ }^{\circ} \mathrm{C}$ for 3.5 months, $\mathrm{y}=79.4 \mathrm{e}^{-0.0074 x}, \mathrm{r}=0.89^{* * *}$

$\mathrm{B}=$ parallel storage at $+5-+10^{\circ} \mathrm{C}$ for 7 weeks, $y=77.8 \mathrm{e}^{-0.0122 \mathrm{x}}, \mathrm{r}=0.96^{\text {*Hस }}$

of healthy cabbages, about $0.1 \% /$ day. The storage losses for cabbages with a B. cinerea content of $90 \%$ were already $0.34 \%$ /day during a storage period of 6.5 months. As the damage caused by the fungus in the main does not develop until after 4 months storage (TAHVONEN 1981), the information provided by parallel storage about the storagability of the cabbage crop can be easily utilized when deciding the best time for marketing the cabbages. One disadvantage in this study was that no observations were obtained about $B$. cinerea contents over the range $40-80 \%$, which would have been essential for determining the more important damage threshold values. According to the material of this study, B. cinerea contents of less than $40 \%$ do not significantly weaken the merchantability of the cabbages (Table 1). The results obtained in this and earlier studies would suggest that the harmful $B$. cinerea limit is between $50-60 \%$, which would presuppose that the products should be marketed, at the latest, by the end of February (in the fifth month of storage).

It would be necessary to be able to identify $B$. cinerea on cabbages in parallel storage by visual means. However, when such storage is carried out at higher temperatures, the Rhizoctonia solani Kühn disturbs and makes identification difficult. As it is a fast-growing fungus it can spread from infected plants to most of the cabbages within $5-7$ weeks at $5-10^{\circ} \mathrm{C}$. $R$. solani is also known to be a storage pathogen (WELLMAN 1932, WALKER et al. 1958, ADAIR 1971), but is of no significance in refrigerated stores (TAHVONEN 1981).

It has already been shown in an earlier study that $B$. cinerea can be effectively controlled by spraying the plants in the field with fungicide 1-2 weeks before harvesting (TAHVONEN 1981). In the two-year experiment described here, even spraying carried out 4 weeks before harvesting controlled, to a satisfactory degree, $B$. cinerea on cabbages to be stored. This would indicate that infection of the cabbages mainly takes place 3 weeks or more 
before harvesting, assuming that the effect of the fungicide treatment disappears in about one week. A cold and very wet period at the end of September and beginning of October, near to harvesting time, appears to inhibit the spread of the conidia (cf. CHASTAGNER et al. 1978).

\section{References}

ADAIR, G. N. 1971. Influence of controlled atmosphere storage condition on cabbage postharvest decay fungi. Pl. Dis. Rep. 55: 864-868.

BOCHOW, H., HOFFMANN, K., KUMPF, S. \& MEINL, G. 1976. Über das Anfälligkeitsverhalten verschiedener Kopfkohlsorten während der Lagerung gegenüber Botrytis cinerea Pers. Arch. Phytopath. und Pfl.schutz 12: 261-273.

BROWN, A. C., KEAR, R. W. \& SYMONS, J. P. 1975. Fungicidal control of Botrytis cinerea on coldstored white cabbage. Proc. 8th Brit. Insectic. Conf. 1975: 339-346.

CHASTAGNER, G. A., OGAWA, J. M. \& MANJI, B. T. 1978. Dispersal of conidia of Botrytis cinerea in tomato fields. Phytopath. 68: 1172-1176.

KEAR, R. W., WILLIAMS, D. J. \& STEVENS, C. C. 1977. The effect of iprodione on the fungal deterrioration of stored white cabbage. Proc. 9th Brit. Insectic. Fungic. Conf. 1977: 189-195.

LOCHART, C. L. 1976. Reducing disease losses in stored cabbage. Can. Agric. 21: 9-10.

SEIDEL, M. \& BARESEL, F. 1978. Der Einsatz Spriztunnels zur Behandlung von Kopfkohl gegen Lagerfäulen in der LPG "Am Meer des Friendens" Elmerhorst. Nachr. bl. Pfl. schutzd. in der DDR 32: 55-56.

STRUC, P. \& CRUTZ, E. M. 1972. Erfolgreiche Lagerung von Kopfkohl. Gartenb. 19: 201-202.

SUHONEN, I. 1969. On the storage life of white cabbage in refrigerated stores. Acta Agr. Scand. 19: $18-32$.

TAHVONEN, R. 1981. Storage fungi of cabbage and their control. J. Scient. Agr. Soc. Finl. 53: 211-227.

WALKER, J. C., CARSON, R. H. \& TAYLOR, A. L. 1958. Disease of cabbage and related plants. U. S. Dep. Agric. Handb. No 144.

WELLMEN, F. L. 1932. Rhizoctonia -bottom rot and heat rot of cabbage. J. Agr. Res. 45: 461-469.

Ms received April 12, 1983

SELOSTUS

Lyhytaikainen rinnakkaisvarastointi Botrytis cinerea Pers ex Fr. -sienen aiheuttamien varastotappioiden ennustamisessa keräkaalilla

\section{Risto Tahvonen}

Helsingin yliopiston kasvipatologian laitos, 00710 Helsinki 71

Uusi osoite: Maatalouden tutkimuskeskus, kasvitautiosasto, 3160 Jokioinen

Vuosina 1980-1981 kasvatettiin keräkaaleja 'Faalen sinikärki', joille tehtiin 1-4 viikkoa ennen sadonkorjuuta fungisidiruiskutukset benomyylillä (Benlate), vinklotsoliinilla (Ronilan) 
ja disyklidinellä (Sumisclex). Tavoitteena oli saada kaalieriä, joissa oli vaihtelevia Botrytis cinerea Pers ex Fr. -pitoisuuksia. Osa kaaleista varastoitiin $+1{ }^{\circ} \mathrm{C}: s s a 6.5$ kuukautta ja osa varastoitiin $1.5,2.5$ ja 3.5 kuukautta $+1{ }^{\circ} \mathrm{C}$ :ssa sekä osa 3,5 ja 7 viikkoa $+5-+10^{\circ} \mathrm{C}$ :ssa. Kaalit pidettiin 30-40 kg:n rei'itetyissä muovipusseissa korkean suhteellisen kosteuden ylläpitämiseksi. Pitkään varastoiduilta kaaleilta määritettiin varasto- ja kauppakunnostustappiot sekä taudit. Rinnakkaisvarastoiduilta kaaleilta tunnistettiin vain taudit, joiden pitoisuuksilla pyrittiin ennustamaan normaaliajan varastoitujen kaalien säilyvyyttä.

Rinnakkaisvarastoitujen, 3.5 kuukautta $+1{ }^{\circ} \mathrm{C}$ :ssa tai 7 viikkoa $+5-+10^{\circ} \mathrm{C}$ :ssa, keräkaalien $B$. cinerea -pitoisuuksilla voitiin luotettavasti ennustaa 6.5 kuukautta varastoitujen kaalien $B$. cinera -pitoisuus ja samalla varastotappiot. Terveillä kaaleilla olivat kunnostus-, haihduntaja hengitystappiot vain $0.1 \%$ vuorokausi, mutta pahasti $B$. cinerea - sienen saastuttamilla kaaleilla $0.34 \%$ /vuorokausi 6.5 kuukauden varastoinnissa. Alle $40 \%$ :n $B$. cinerea -pitoisuus ei vielä aiheuttanut merkittäviä varastotappioita. Haitallinen $B$. cinerea -pitoisuus on ilmeisesti $50-60 \%$, jolloin tuotteet olisi markkinoitava helmikuun loppuun mennessä, sillä muutoin tautien aiheuttamat varastotappiot lisääntyisivät erittäin nopeasti.

$B$. cinerea -sieni oli tunnistettavissa silmävaraisesti rinnakkaisvarastoiduista kaaleista, jolloin menetelmä on sovellettavissa sellaisenaan kaupallisillekin varastoille, erityisesti suurille yhteisvarastoille, joissa on usean eri viljelmän kaaleja. 